\title{
Analysis of Climate Variability and Drought Frequency Events on Limpopo River Basin, South Africa
}

\section{Sintayehu Legesse Gebre ${ }^{1^{*}}$ and Yitea Sineshaw Getahun ${ }^{2}$}

${ }^{1}$ Department of Natural Resources Management, Jimma University, PO Box 307, Jimma, Ethiopia

${ }^{2}$ Department of Natural Resources Management, Debre Birhan University, Dibre Birhan, Ethiopia

"Corresponding author: Gebre SL, Department of Natural Resources Management, Jimma University, PO Box 307, Jimma, Ethiopia, Tel: +251471123170; E-mail: sintayehulegesse@gmail.com

Rec date: Apr 26, 2016; Acc date: Jun 27, 2016; Pub date: June 30, 2016

Copyright: $\odot 2016$ Gebre SL, et al. This is an open-access article distributed under the terms of the Creative Commons Attribution License, which permits unrestricted use, distribution, and reproduction in any medium, provided the original author and source are credited.

\begin{abstract}
This study has analyzed the climate variability and meteorological drought events over Limpopo River Basin. The Limpopo Basin is shared by four countries, Botswana, South Africa, Zimbabwe, and Mozambique. The total catchment is approximately $408,000 \mathrm{~km}^{2}$. The main governing factor for rainfall patterns in the basin is the movement of the Inter-tropical Convergence Zone (ITCZ). In this study the drought event has been analyzed using standardized precipitation index (SPI). The SPI quantifies the precipitation deficit for multiple time scales and reflects the impact of droughts on the availability of water resources. The long year's daily average monthly precipitation for the whole area indicates that the precipitation is variable and there is no any clear trend. The relative percentage change of average monthly precipitation of the 1992-2001 compared to 1961-1991 period using WATCH Climate data of the River basin indicates that, a positive value increase in percentage change is observed for the whole months of the year. High magnitude deviation in maximum and minimum temperature in the month of July 2001 observed with respect to 1961-2000 period. 5.2 and 7.9 degree centigrade respectively. The long term SPI analysis indicates that there was an extended accumulated sever dry condition that is prolonged from 1991 up to 1992 over the basin. Generally, this study indicates that there is a frequent meteorological drought events and unpredictable climate variability in the basin. Therefore farmers should take a precaution to adjust their farming system and to overcome drought events for better agricultural productivity.
\end{abstract}

Keywords: Climate; Drought; WATCH; SPI; Limpopo River basin

\section{Introduction}

Around the world, particularly more than 200 million people living in Southern Africa, frequently has been affected by recurring drought events that affects the socio-economic of the people. The impacts has been exacerbated by the climate variability, due to erratic and un predictable nature of seasonal rainfall, floods and cyclones which highly affects the farming system across southern Africa, especially rain fed agricultural and low lying areas [1]. In the last decades, droughts become more frequent in the Limpopo River Basin. Normally, droughts are long term hydro-meteorological events which affect large regions and results a huge significant impacts on different sectors of development. The impact is persistent in semi arid and arid areas. Droughts are natural disaster in the world and affect more people than floods, due to its wider spatial coverage. Main drought characteristics include the onset, termination time, severity and frequency [2-5]. Drought is a slowly-developing phenomenon that seriously affects human life and mal nourishes children in different corner of the world. According to a report by the United Nations Development Program (UNDP) states that drought is considered by many to be the most complex and least understood of all natural hazards, affecting more people than any other hazard [6]. It is one of the most chronic natural disasters in Southern Africa in terms of social, economical and environmental aspects [7]. There are different type's drought like agricultural drought, hydrological drought, socio economic drought and meteorological drought. In this is study the prominent drought is investigated that is meteorological drought: It is a reduction in rainfall supply compared with a specified average condition over some specified period; defined as a period during which less than a certain amount (e.g., 70 percent) of the normal precipitation is received over any large area for an extended period [4].

There are a lot of different drought indices have been applied to quantify and measure droughts. The most commonly used meteorological drought indices provided by Ref. [8] are the Palmer Drought Severity Index (PDSI) and the standardized precipitation index (SPI). The Palmer Drought Severity Index (PDSI) has been widely used to study degree of changes in aridity in modern and past climates, and different kinds of DPSI are developed over years in different parts of the world. SPI is more representative of short-term precipitation than the Palmer Index, and is therefore a better indicator of soil moisture variation and soil wetness [9]. In this study the focus of drought analysis is on short- term drought, therefore using of SPI is advantageous. The SPI quantifies the precipitation deficit for multiple time scales and reflects the impact of droughts on water resources availability of a given region. Wetter and drier climates can be represented in the same way by the SPI, because it is a normalized index [2-4]. The main objective of this study is to analyze temporal climate variability and meteorological drought sensitive of the Limpopo River basin.

\section{Description of the Study Area}

The Limpopo Basin is shared by four countries, Botswana, South Africa, Zimbabwe, and Mozambique. The total catchment is approximately $408,000 \mathrm{~km}^{2}$. The populations of these four countries combined are approximately 81.5 million people in $2007,18 \%$ of which 
are living in the Limpopo Basin. Also the topography in the river basin varies from above 2,000 meter above sea level (MASL) in the mountain regions of South Africa to 7 MASL in the vast flood plains of Mozambican part of the catchments. The last $175 \mathrm{~km}$ of river stretch has elevations below 7 MASL. This also influences the climate in the basin. The climate ranges from tropical dry savannah and hot dry steppe to cool temperatures in the mountainous areas. The main governing factor for rainfall patterns in the basin is the movement of the Inter-tropical Convergence Zone (ITCZ). The average rainfall of the basin is $530 \mathrm{~mm}$ per year, ranging from 200 to $1,200 \mathrm{~mm} / \mathrm{y}$, while the average evaporation is $1,970 \mathrm{~mm} / \mathrm{y}$, ranging from 800 to 2,400 $\mathrm{mm} / \mathrm{y}$. The areas that receive the highest rainfall are the mountainous areas in South Africa, while the lowest rainfall is usually found along the Limpopo River between Zimbabwe and South Africa [10].

\section{Materials and Methods}

\section{Estimation of areal precipitation}

A single point precipitation measurement is quite often not representative of the volume of precipitation falling over a given catchment area. In order to compute the areal precipitation over Limpopo River Basin of the gridded watch data. The areal of each grid which falls on the catchment was calculated using GIS. The weighted contribution precipitation of each grid was determined using theissen polygon method (Table 1).

\section{Pave $=$}

$\mathrm{Wi}=1 / \mathrm{m}$

Pave $=$ Average (Areal precipitation) in $\mathrm{mm}$.

$\mathrm{Pi}=$ Precipitation of each grid $(\mathrm{mm})$

In the Theissen polygon method,

$\mathrm{Wi}=\mathrm{Ai} / \mathrm{AT}$

Where,

$\mathrm{A} i=$ Area of the grid

$\mathrm{AT}=$ Total area of the catchment

\begin{tabular}{|l|l|l|}
\hline Dataset & Type & Analyses Period \\
\hline Climate modelled data & WATCH & $1961-2001$ \\
\hline & CORDEX & $1961-2050$ \\
\hline Ground observation & Meteorological stations & $1998-2006$ \\
\hline
\end{tabular}

Table 1: Data used for analysis.

\section{Standard Precipitation Index (SPI)}

The software used: SPI_SL_6.exe (Sources of the software:// drought.unl.edu/Monitoring Tools/DownloadableSPIProgram.aspx National Drought Mitigation Centre). National Drought Mitigation Center, International Drought Information Center University of Nebraska-Lincoln. This software was selected for analysis of drought over the Limpopo River basin because of simple input requirement, wide applicability and easily accessible.

Drought events analysis using Standard Precipitation Index (SPI) was developed by Ref. [11]. One of the main merits of using the SPI is that, it only requires precipitation data as input, which makes it ideal for regions where data collection is expensive and difficult. The fact that the SPI is based solely on precipitation makes its evaluation relatively easy [12]. The SPI is a standardized index. Standardization of a drought index ensures independence from geographical position as the index in question is calculated with respect to the average precipitation in the same place [12].

The standard precipitation index (SPI) is used to quantify precipitation for different time scale for any given location. The multiple times scale indicates the extent of the precipitation deficiency, normally the precipitation anomaly from the normal trend reflected at short time scale on soil moisture, latter to ground water, stream flow and reservoir storage. The SPI is calculated for 1, 3, 6, 9, 12 and 24 months time scale. SPI calculation requires with a minimum of 30 years of climate (precipitation) data. The computation of the SPI drought index for any location is based on the long term precipitation record (at least 30 years) cumulated over a selected time scale [13]. If the data scale is less than 30 years the confidence the statistical determination becomes less and the time scale of determination goes beyond 24 months, the extreme of wetness and dryness probability distribution becomes weaken. This long term precipitation time series is then fitted to a gamma distribution, which is then transformed through an equal probability transformation into a normal distribution $[12,14]$. Positive SPI values indicate wet conditions with greater than median precipitation and negative SPI values indicate dry conditions with lower than median precipitation [12]. Negative values indicate less than median precipitation. Because the SPI is normalized, wetter and drier climates can be represented in the same way; thus, wet periods can also be monitored using the SPI (Table 2).

\begin{tabular}{|l|l|}
\hline SPI Values & Class \\
\hline$>2$ & Extremely wet \\
\hline $1.5-1.99$ & Very wet \\
\hline $1.0-1.49$ & Moderately wet \\
\hline-0.99 to 0.99 & Near normal \\
\hline-1 to -1.49 & Moderately dry \\
\hline-1.5 to -1.99 & Very dry \\
\hline$<-2$ & Extremely dry \\
\hline
\end{tabular}

Table 2: Drought Classification based on SPI [12].

In order to statistically analyze the data, the distributions of raw data are fit with a smooth curve. Gamma distributions [14] are well suited for describing the shapes of the distributions of monthly and seasonal precipitation. The shape and scale parameters of the gamma distribution are estimated for the region for each time scale for each month of the year using the empirical probabilities of the precipitation data [15]. The running precipitation sums are converted to non exceedance probabilities using the incomplete gamma function. The non exceedance probabilities are then converted to an index value using the inverse normal function. This transforms the data from a skewed distribution to a standard normal distribution with a mean of zero and variance of one (i.e., the bell-shaped curve) using the methodology of Abramowitz and Stegun [16]. In this form, the SPI becomes essentially the number of standard deviations an event is above or below the mean value. 
Citation: Gebre SL, Getahun YS (2016) Analysis of Climate Variability and Drought Frequency Events on Limpopo River Basin, South Africa.

\section{Results and Discussion}

Spatial and temporal climate trend analysis of Limpopo

\section{River basin}

Temporal Precipitation Analysis Result of Limpopo River Basin

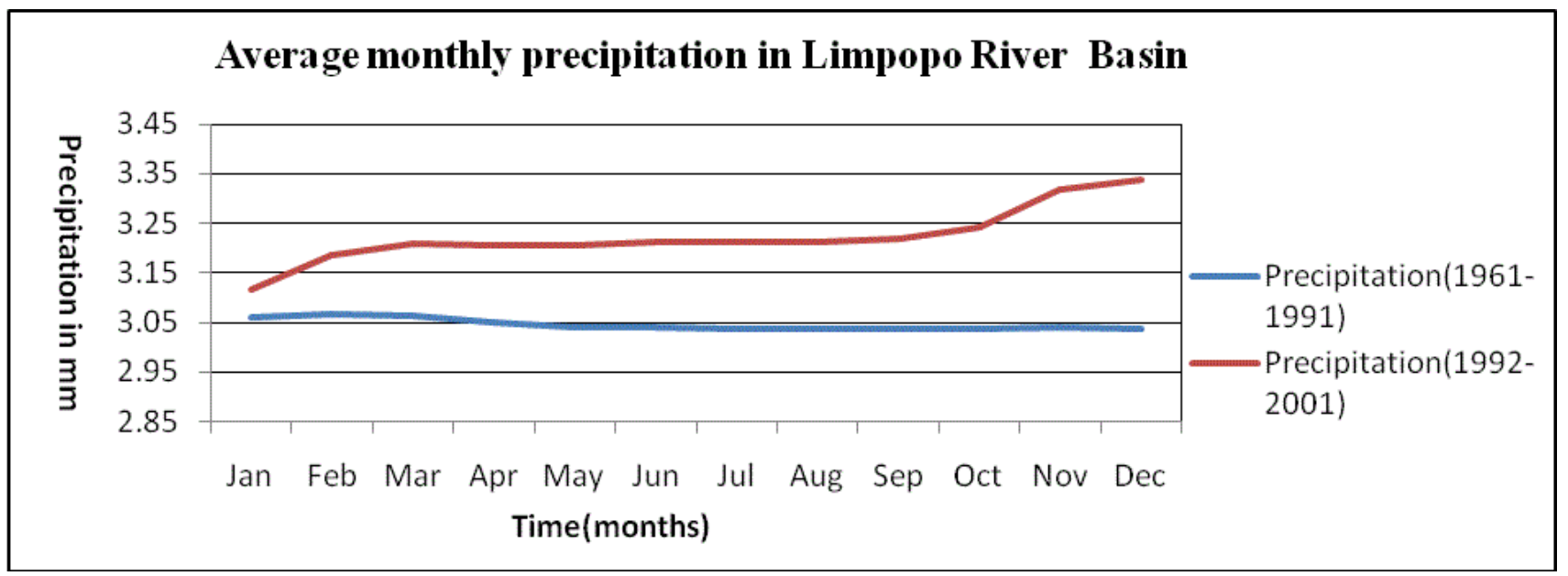

Figure 1: Average monthly precipitation of WATCH climate data in Limpopo River Basin (1961-1991 and 1992-2001).

Figure 1 shows average monthly temporal comparison of areal precipitation of Limpopo River Basin. There is an increasing trend of average monthly precipitation from 1992-2001 compared to the long term average precipitation. This relative increment of does not mean that it increases in each particular part of the River basin, since the areal precipitation is the average of the area. The quantification of the relative percentage change is described in Figure 2.

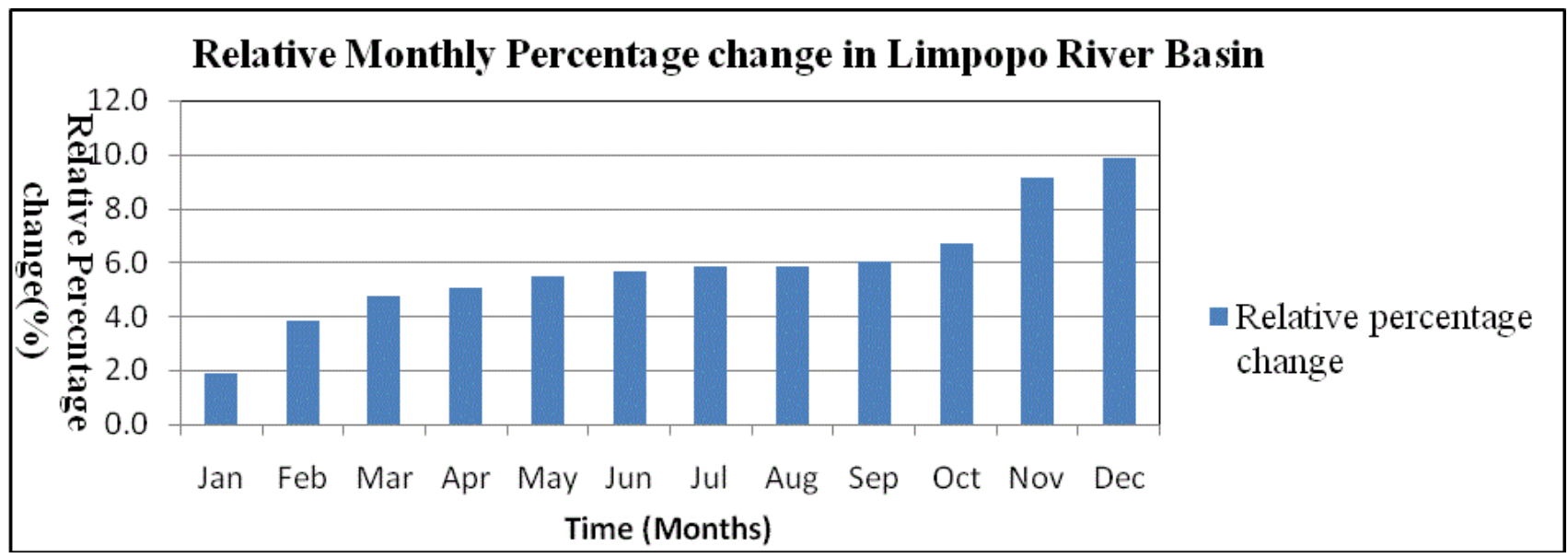

Figure 2: Relative long term average monthly precipitation change (\%) of 1992-2001 with respect to 1961-2001 of WATCH climate data in Limpopo River Basin.

The relative percentage change of average monthly precipitation of the 1992-2001 compared to the 1961-1991 period of the River basin analysis indicates that, a positive value increase in percentage change is observed for the whole months of the year. However the relative change in each month of the year is different. Maximum change is observed in December and the minimum in January.

\section{Temporal temperature analysis result in Limpopo River} basin

A random single grid cell in the lower arid area of the River basin taken for the analysis of comparison of the long year's average maximum and minimum Temperature of 1961-2000 with respect to 2001 year. This is only to see the relative change and pattern of the long term average monthly minimum and maximum temperature with 
Citation: Gebre SL, Getahun YS (2016) Analysis of Climate Variability and Drought Frequency Events on Limpopo River Basin, South Africa.

Page 4 of 7

respect to a random one year. The grid cell selected randomly in the south west of the River Basin bordering in between South Africa and Botswana.

\section{Maximum temperature}

The long years maximum temperature trend is more or less constant compared to 2001 maximum temperature. This is because the long year's average monthly of the maximum temperature is less variable; normally temperature variability in the tropics particularly in arid areas is negligible. However, the relative comparison with 2001 is significant, especially during winter and summer (Figure 3).

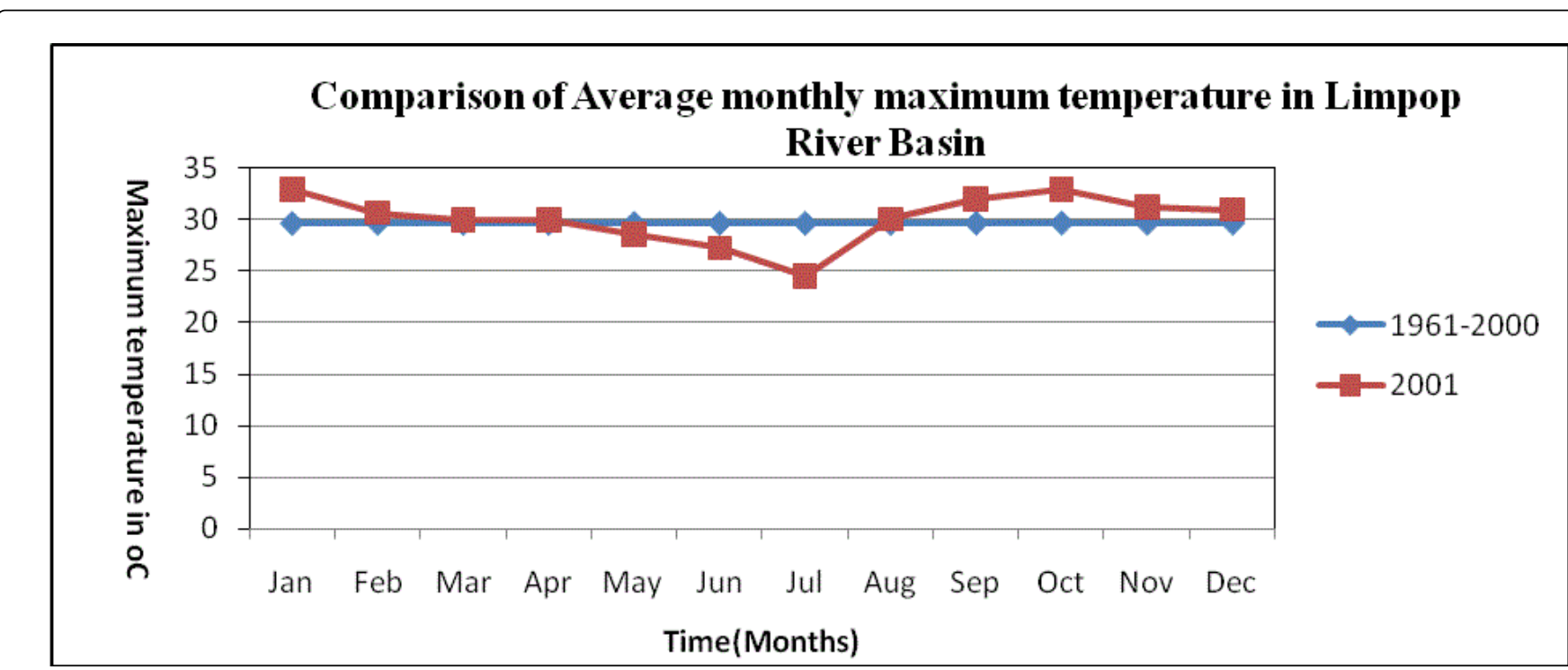

Figure 3: Average Maximum temperature of WATCH climate data comparison of 2001 with respect to 1961-2000 over Limpopo River Bain.

\section{Minimum temperature}

The long year's average minimum temperature has different pattern to the one year minimum temperature of the particular grid location in the area. As like the maximum temperature, the minimum temperature pattern of 2001 is quite different in relation to the long term average monthly minimum temperature (1961-2000). Significant magnitude variability is noticed in the average monthly minimum temperature, particularly during summer and winter seasons (Figure 4).

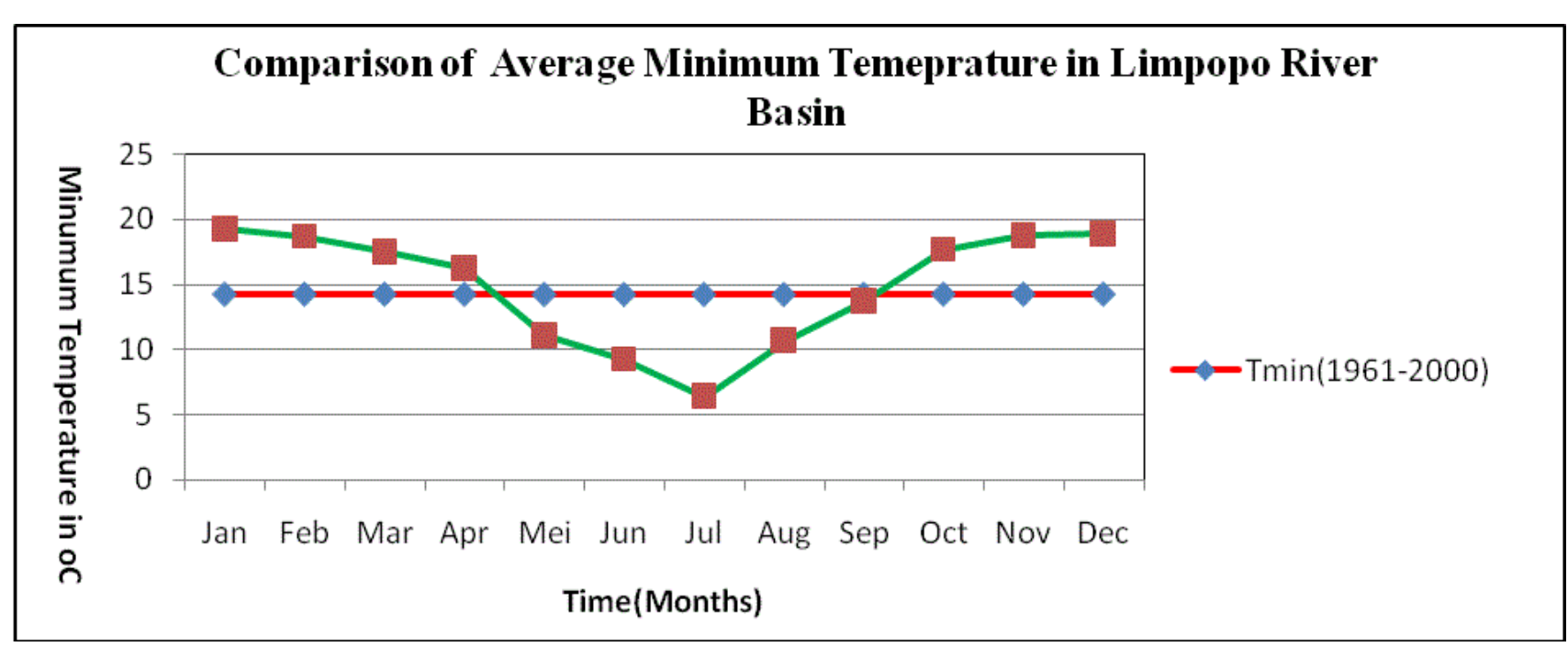

Figure 4: Average Minimum temperature of WATCH climate data comparison of 2001 with respect to 1961-2000 over Limpopo River Basin. 
Citation: Gebre SL, Getahun YS (2016) Analysis of Climate Variability and Drought Frequency Events on Limpopo River Basin, South Africa.

Page 5 of 7

\section{Standard Precipitation Index (SPI) analysis using WATCH climate data}

The one month SPI for October shows that, there are sever dry and wet extreme events happened in the area. In 1962, 1965, 1968, 1975 and 1991 there were sever dry events, while in 1963, 1969, 1978 and 1988 wet events occurred. Over all after 1991 there was not extreme event in the River basin noticed. According to study conducted on drought using SPI, the frequency of drought increases for short term period, when the duration of analysis increases the frequency of drought event decreases [17] (Figures 5 and 6).

The occurrence of the extreme events in the six months standard precipitation shows less compared to the one month standard precipitation index. There were extreme sever dry events in 1973, 1983 and 1992. The extreme wet events also occurred in 1972, 1977 and
2000. Here the six months standard precipitation index analysis for the end of the growing season of maize shows that the prolong accumulation of the extreme precipitation events in the whole River basin, which has a significant indication of the midterm drought condition for better insight understanding of the water (moisture) availability in the area. A six month SPI analysis conducted at the western part of Limpopo River basin has also indicated drought frequency events in the same fashion as specified in this study [18].

The extreme sever dry events occurred only in 1982 and 1992 while the extreme wet events in 1972, 1975, 1975 and 2000. This long term standard precipitation index analysis indicates that the extension of the extreme events in the River basin. These extreme drought events may have impacts in the entire Limpopo River basin [18] (Figure 7).

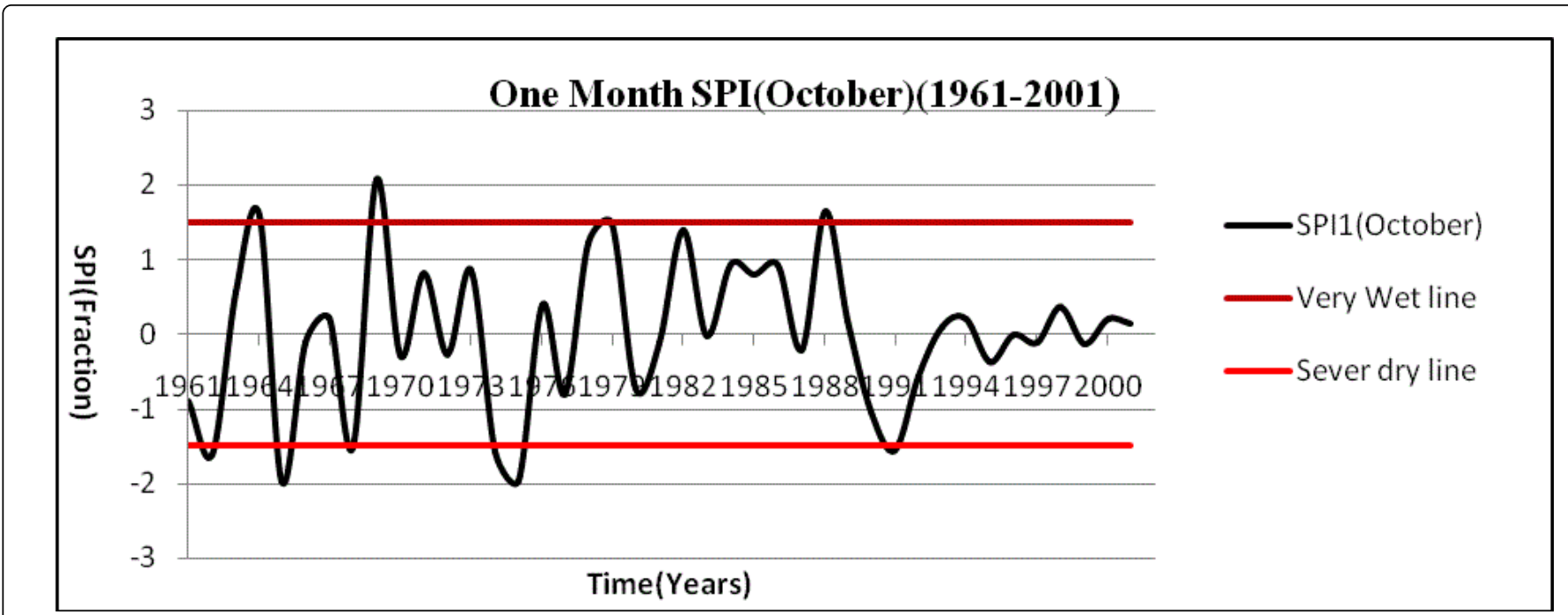

Figure 5: One month Standard Precipitation index for October (1961-2001) for Limpopo River Basin.

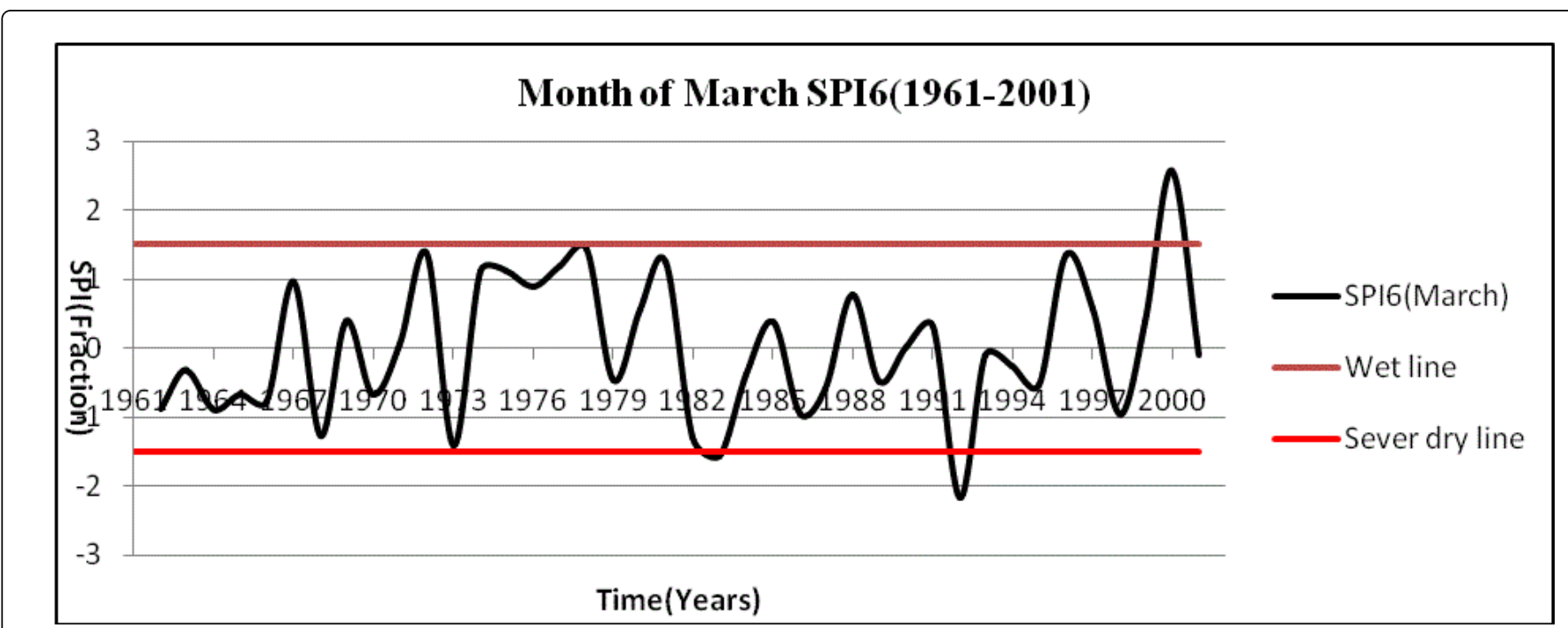

Figure 6: Six month Standard precipitation index of March (1961-2001) using WATCH climate data for Limpopo River Basin. 


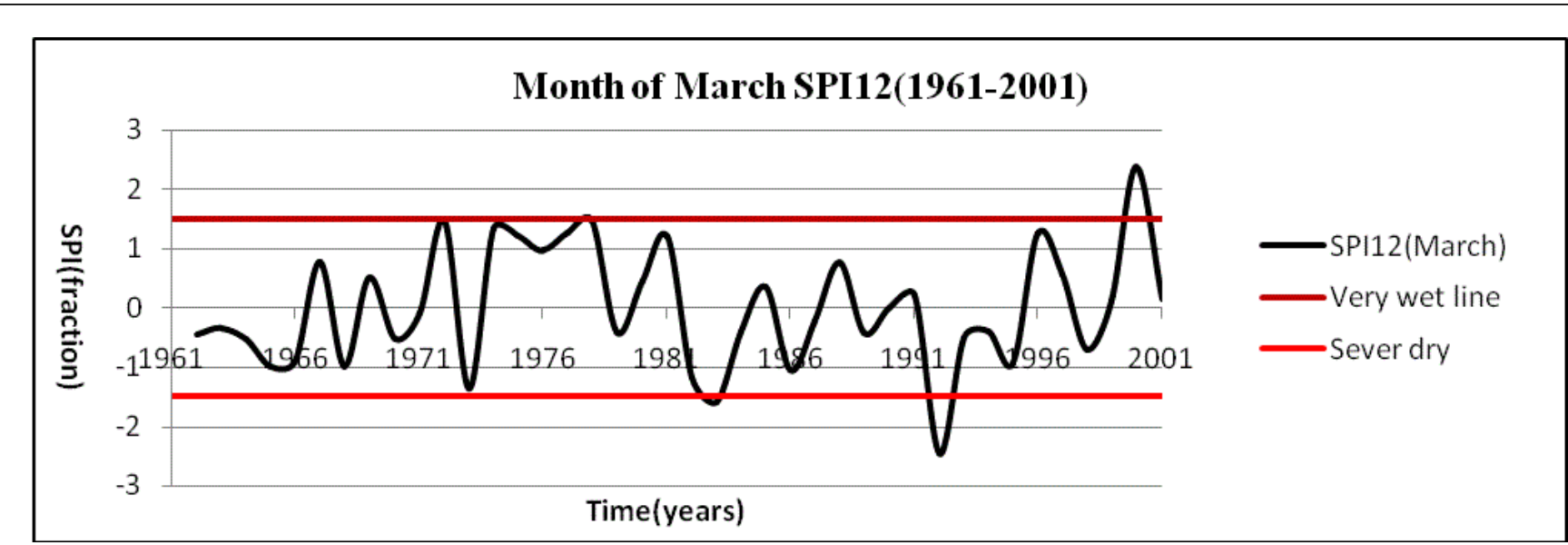

Figure 7: Twelve months standard precipitation index of March (1961-2001) using WATCH climate data for Limpopo River Basin.

\section{Conclusion}

\section{Temporal and spatial variability of precipitation and temperature}

The long year's daily average monthly precipitation for the whole area indicates that the precipitation is variable and there is no any clear trend. Farmers should be aware of the unpredictable nature of the rainfall pattern, for better coping mechanism of the farming system.

The temporal areal precipitation comparison from 1992-2001 with respect to 1961-1991 shows a positive incremental relative precipitation change throughout the months of the year observed in the range from $1.9-9.9 \%$.

The temporal maximum and minimum temperatures for a single grid cell in the lower end of the basin taken for analysis. In order to see the long years average temperature temporal comparison with an individual year. High magnitude deviation in maximum and minimum temperature in the month July of 2001 observed from the long years average (1961-2000), 5.2 and 7.9 degree centigrade respectively. In the rest of the months of the year the variation is small.

\section{SPI analysis (Extreme indices)}

The SPI analysis carried out into consideration of the growing season of Maize, since Maize is the most stable cereal crop in the area. The time horizon taken for the modelled WATCH climate data is from 1961-2001.

The one month SPI October for the river basin considered for analysis to give an indication for sowing month of October for better understanding of farmers` sowing schedule.

The SPI1 October shows that there were frequent extreme events occurred especially in the 1960`s and 70`s, however after 1991 there was no any extreme event happened.

The SPI6 march analysis indicates that there were frequent extreme events occurred particularly in 1970's and 80's, Moreover extreme events also observed after 1991 which makes it different from the SPI1, which exeplicility determine the short term precipitation condition an area [17].
The SPI 12 March, shows less frequent occurrence of extreme events compared to the other one $\mathrm{m}$ and six month SPI analysis. This long term SPI analysis indicated that there was an extended accumulated sever dry condition that is prolonged, which is not vividly noticed in the one month SPI. In SPI 1 there was no any extreme events after 1991 but extreme event clearly showed in 1992 both in SPI 6 and SPI 12. The 1991 extreme event might be extended into 1992.

\section{Recommendation}

The temporal precipitation and temperature analysis for the Limpopo Basin, is using WATCH climate model data, there might be some unforeseen uncertainty with the model assumption which might arise in the reliability of the result. Moreover the precipitation is taken for the whole area, the areal precipitation is considered as average precipitation over the basin, so the result represent the average precipitation of the area rather than the specific places in the basin. The temperature analysis is considered simply one grid cell, not the whole grid cells; therefore it should be taken into consideration.

We strongly recommend for future work to take different climate model data output with high resolution and to see the spatial and temporal variability over the area for better understanding of climate variability in the Limpopo Basin.

\section{Acknowledgements}

The authors would like to thank (Alterra Group, Wageningen University) for providing WATCH climate data for the study. Our gratitude extends to Dr. RWA Hutjes for his endeavor support in supervising the Limpopo River Basin project (Earth System Science Group, Wageningen University).

\section{References}

1. Gommes R (2006) Data issues in climate related risk and impact assessments for food security. Living with Climate conference.

2. Loukas A, Vasiliades L (2004) Probabilistic Analysis of Drought Spatiotemporal Characteristics in Thessaly Region, Greece. Natural Hazards and Earth Systems Science 4: 719-731.

3. American Meteorological Society (2004) Statement on Meteorological Drought. Bulletin of the American Meteorological Society 85: 771-773. 
Citation: Gebre SL, Getahun YS (2016) Analysis of Climate Variability and Drought Frequency Events on Limpopo River Basin, South Africa. Hydrol Current Res 7: 249. doi:10.4172/2157-7587.1000249

Page 7 of 7

4. Wilhite DA, Glantz MH (1985) Understanding the Drought Phenomenon: The Role of Definitions. Water International 10: 111-120.

5. Dracup JA, Lee KS, Paulson EG (1982) On the Definition of Droughts. Water Resources Research 16: 297-302.

6. United Nations Special Office (1999) International workshop on coping with drought: best use of climate information for farmer decision making. Kadoma Ranch, Zimbabwe, 4-6 October.

7. Buckland R, Eele G, Mugwara R (2000) Humanitarian crises and natural disasters: a SADC perspective. In Clay E and Stokke O (eds). Food aid and human security. European Association of Development Research. London, Frank Cass Publishers.

8. Palmer WC (1965) Meteorological Drought. Weather Bureau Research Paper, US Weather Bureau, Washington DC, USA 45: 1-58.

9. Mishra AK, Singh VP (2010) A review of drought concepts. Journal of Hydrology 391: 202-216.

10. Republic of Mozambique, Ministry of Public Works and Housing, National Directorate of Water (2010) Joint Limpopo River Basin Study Scoping Phase. Limpopo Basin Permanent Technical Committee LBPTC.

11. McKee TB, Doesken NJ, Kleist J (1993) The relationship of drought frequency and duration of time scales. Eighth Conference on Applied Climatology, American Meteorological Society, Anaheim, CA, USA, pp: 179-186.
12. Cacciamani C, Morgillo A, Marchesi S, Pavan V (2007) Monitoring and Forecasting Drought on a Regional Scale: Emilia-Romagna Region. In "Methods and Tools for Drought Analysis and Management" (eds.). Rossi GT, Vega B, Bonaccorso B. Springer Netherlands 68: 29-48.

13. Bordi I, Sutera A (2007) Drought Monitoring and Forecasting at LargeScale. In: Rossi G, Vega T, Bonaccorso B (eds.). Methods and Tools for Drought Analysis and Management, Springer-Verlag, New York Inc., New York, USA, pp: 3-27.

14. Guttman NB (1999) Accepting the Standardized Precipitation Index: A Calculation Algorithm. Journal of the American Water Resources Association 35: 311-322.

15. Thom HCS (1999) Same methods of climatological analyses. World Meteorological Organization, Geneva, p: 53. WMO, TP, 103, Technical note: 81 .

16. Abramowitz S (1965) Handbook of Mathematical Functions. National Bureau of Standards Applied Mathematics Series 55.

17. Luong BN, Qiong FL (2015) Adaptive Neuro-Fuzzy Inference System for Drought Forecasting in the Cai River Basin in Vietnam. J Fac Agr Kyushu Univ 60: 405-415.

18. Berhanu F, Alemaw JM, Kileshye O, Love D (2013) Regional Drought Severity Assessment at a Basin Scale in the Limpopo Drainage System. Journal of Water Resource and Protection, pp: 1110-1116. 